\title{
STRATEGI PEMBERDAYAAN MASYARAKAT UNTUK PENGEMBANGAN EKOWISATA WILAYAH PESISIR DI KABUPATEN BULELENG
}

\author{
I Putu Ananda Citra \\ Jurusan Pendidikan Geografi, Universitas Pendidikan Ganesha \\ Singaraja, Indonesia
}

e-mail: anandageo07@yahoo.com

\begin{abstract}
Abstrak
Penelitian ini dilaksanakan di wilayah pesisir Kabupaten Buleleng dengan tujuan 1) mendeskripsikan potensi sumber daya pesisir untuk pengembangan ekowisata, 2) Menganalisis strategi pemberdayaan masyarakat untuk pengembangan potensi ekowisata di pesisir Kabupaten Buleleng. Metode yang digunakan dalam penelitian ini adalah survai didukung dengan metode observasi. Pengambilan sampel dengan teknik purposive sampling. Analisis data dilakukan dengan teknik analisis deskriptif kualitatif dan analisis SWOT. Hasil penelitian menunjukkan, 1) Sumber daya pesisir di Kabupaten Buleleng yang meliputi: (1) sumber daya hayati yaitu potensi perikanan dan terumbu karang, (2) sumber daya buatan yaitu dermaga dan (3) sumber daya jasa-jasa lingkungan yaitu keindahan terumbu karang, atraksi lumba-lumba dan pemandangan sunset sebagai potensi ekowisata. 2) Strategi pengembangan sumber daya pesisir untuk pemberdayaan masyarakat pembudidayaan ikan, pelestarian terumbu karang, pelatihan peningkatan pelayanan wisata, penyediaan tempat pelelangan ikan, pengadaan modal dan kerjasama bagi usaha-usaha masyarakat dalam membuat kerajinan tangan, penegakan hukum atau awig-awig beserta sanksi, memberikan batasan masuknya produk perikanan dari luar daerah.
\end{abstract}

Kata kunci: Potensi Sumber Daya Pesisir, Pemberdayaan Masyarakat, Wilayah Pesisir

\begin{abstract}
This research was conducted in the coastal region of Buleleng with the purpose of 1) describe the potential of coastal resources for the development of ecotourism, 2) analyzing community empowerment strategies for potential development of ecotourism in the coastal district of Buleleng. The method used in this study is a survey supported by the observation method. Sampling with purposive sampling technique. Data was analyzed using qualitative descriptive analysis techniques and SWOT analyzed. The results showed, 1) Resources coast in Buleleng which includes: (1) the biological resources that is potential for fisheries and coral reefs, (2) made resources, namely docks and (3) the resources of environmental services, namely the reefs, dolphins and sunset views as its ecotourism potential. 2) The development strategy of coastal resources for community empowerment cultivation of fish, coral reef conservation, training to improve tourism services, provision of fish auctions, procurement of capital and cooperation to the efforts of society in making handicrafts, law enforcement or awig awig and penalties, provide limits entry of fishery products from outside the region.
\end{abstract}

Keywords: Potential Coastal Resources, Community Empowerment, Coastal Region 


\section{PENDAHULUAN}

Perencanaan

pembangunan merupakan jalan untuk mewujudkan aspirasi dan tuntutan masyarakat. Pembangunan yang berpusat pada pertumbuhan telah didorong oleh modelmodel ilmu ekonomi sistem terbuka yang konvensional, yang memandang baik orang (manusia) maupun lingkungan sebagai variabel luar. Selain itu, model pembangunan tersebut percaya melalui efek tetesan ke bawah (trickle down effect), yakni bila terjadi akumulasi kapital dikalangan kelas atas atau pusat, maka kapital itu akan menetes ke bawah. Karena itu lewat mekanisme semacam itu pula perbaikan hidup rakyat pedesaan, yang mayoritas miskin, diharapkan dapat terwujud. Kritik dan kecaman terhadap doktrin developmentalisme itu terus mengalir, mulai dari penganut paradigma kebutuhan pokok, teori ketergantungan sampai dengan pendekatan dan gerakan baru yang mengarah pada pemberdayaan. Gerakan pemberdayaan diawali dari munculnya paradigma pembangunan yang berpusat pada manusia (rakyat), yang diakui sebagai "pembangunan alternatif".

Pariwisata sebagai sub sektor ekonomi, merupakan industri terbesar dan tercepat perkembangannya di dunia. Prioritas pariwisata yang utama dan pertama adalah membangun manusianya, terutama masyarakat lokal dan yang langsung berinteraksi dengan wisatwan agar dapat dicapai kesetaraan dan terjadinya saling pertukaran maupun kerjasama saling menghargai dan memperkaya kehidupan (Baiquni,2010:15). Hal ini berarti, pariwisata selain sebagai sumber pendapatan devisa, media untuk memperluas dan memeratakan kesempatan kerja, mendorong pembangunan daerah, yang paling penting adalah meningkatkan kesejahteraan dan kemakmuran rakyat, media untuk memperkaya kebudayaan nasional agar tetap mempertahankan kepribadian bangsa serta melestarikan fungsi dan mutu lingkungan hidup. Berbekal tekad tersebut, pemerintah mulai memberi perhatian serius untuk sektor pariwisata dan terus menggalakkan kepariwisataan di berbagai daerah sesuai dengan karakter daerah masing-masing. Bali sebagai salah satu daerah tujuan wisata utama di Indonesia banyak memiliki potensi kepariwisataan yang bisa dikembangkan dan ditingkatkan. Kedudukan daerah Bali sudah dapat disejajarkan dengan daerah tujuan wisata lainnya yang ada di dunia.

Walaupun demikian, kesenjangan perkembangan pariwisata di Provinsi Bali masih tetap terjadi yaitu antara Bali bagian utara dengan Bali bagian selatan. Pariwisata seolah putus aktivitasnya di bagian utara Pulau Bali yaitu di Kabupaten Buleleng. Pesatnya perkembangan pariwisata khususnya wisata pantai di Bali bagian selatan seperti Pantai Kuta dan Sanur hampir tidak terjadi pada pesisir Buleleng. Padahal Kabupaten Buleleng memiliki pantai terpanjang di Bali yaitu 157,05 $\mathrm{Km}$ (http://Bulelengkab.go.id). Hal ini berarti bahwa potensi yang dimiliki khususnya potensi wisata pesisir sangat besar untuk dikembangkan. Potensi sumber daya pesisir dan laut di Indonesia begitu beragam baik dari segi kuantitas maupun kualitas, sehingga seharusnya memberikan kontribusi yang sangat penting terhadap pertumbuhan ekonomi Negara Indonesia (Pigawati, 2005).

Ekowisata dan Pemberdayaan masyarakat merupakan bidang kajian Geografi Pariwisata. Berdasarkan latar belakang penelitian yaitu tidak semua DTW memiliki potensi untuk dikembangkan sebagai ekowisata, karena ekowisata memiliki syarat-syarat khusus yang harus dimiliki oleh suatu Daya Tarik Wisata. DTW berbasis ekowisata disamping memiliki sifat ekologis dan ekonomis, hal yang paling penting adalah menjadikan masyarakat di sekitar DTW ikut berpartisipasi aktif dari perencanaan sampai pelaksanaan 
yang akan menciptakan masyarakat yang mandiri.

Salah satu media yang tepat dalam pemberdayaan masyarakat yaitu dalam bidang pariwisata khususnya ekowisata. Bali sebagai salah satu pusat pariwisata di Indonesia, yang memiliki potensi budaya dan alam yang sangat besar, seharusnya memberikan kontribusi yang positif terhadap masyarakatnya. Keanekaragaman potensi sumberdaya pesisir dan ancaman wilayah pesisir terhadap kerusakan penting untuk dikelola dengan melibatkan pihak terdekat yaitu masyarakat pesisir. Pemberdayaan sangat diperlukan agar masyarakat menjadi mandiri dan bertanggung jawab terhadap wilayahnya. Belum ada strategi pemberdayaan sehingga menarik untuk dikaji karena kawasan ekowisata selain merupakan sumber pendapatan masyarakat juga berfungsi untuk konservasi keanekaraganam hayati dan kelestarian budaya masyarakat lokal.

\section{METODE}

Penelitian ini dilakukan di wilayah pesisir Kabupaten Buleleng. Analisis penelitian yang akan digunakan harus tepat untuk menjawab permasalahan penelitian. Dengan demikian hal pertama yang harus ditentukan adalan mengenai pendekatan yang akan digunakan. Penelitian ini menggunakan salah satu pendekatan geografi yaitu pendekatan ekologis. Secara garis besar ada empat tema analisis yang dapat dikembangkan dalam pendekatan ekologis di bidang kajian geografi (Yunus,H.S, 2010:94). Terkait dengan permasalahan penelitian, tema analisis yang digunakan adalah analisis interaksi antara kegiatan manusia dengan lingkunganya. Manusia selain sebagai sosok biologis juga sebagai sosok yang berbudaya. Artinya bahwa manusia mempunyai sosok sosial, ekonomi, politik, dan religius dalam menyelenggarakan kehidupannya yang tercermin pada perilaku tertentu (behavior) dalam komunitasnya dan sebagai pembeda dengan makhluk lainnya. Daya rasa, karsa, cipta, dan karya yang sangat dinamis yang dimiliki manusia dalam meyelenggarakan kehidupannya sebagai modal dasar pemberdayaan dan pembangunan dalam masyarakat.

Pengambilan sampel wilayah dilakukan secara purposive area sampling, karena objek wisata yang berada di wilayah pesisir Kabupaten Buleleng tersebar dari daerah pesisir bagian timur sampai barat. Pembagian 3 zone wilayah Kabupaten Buleleng dijadikan dasar dalam pengambilan sampel objek wisata, yaitu sampel objek wisata yang berada di wilayah pesisir timur (Air Sanih), pesisir tengah (Lovina), dan pesisir barat (Desa Pemuteran). Pengambilan sampel masyarakat dilakukan secara purposive pada area sample yang sudah ditentukan yaitu masyarakat pesisir yang dapat memenuhi syarat atau mewakili untuk kepentingan penelitian, serta mewakili kelengkapan unsur-unsur yang akan diamati dan dinilai berkaitan dengan kegiatan pariwisata di Kabupaten Buleleng.

Data yang dikumpulkan yaitu dengan cara observasi, wawancara, kuisioner dan kajian pustaka. Selanjutnya pengolahan data dengan analisis kualitatif pada masing-masing indikator untuk dapat mendeskripsikan potensi sumber daya pesisir dan Analisis SWOT digunakan untuk merumuskan rencana strategis dalam pemberdayaan masyarakat di wilayah pesisir.

\section{HASIL DAN PEMBAHASAN \\ Potensi Sumber Daya Pesisir di Wilayah Kabupaten Buleleng}

Luasnya wilayah pesisir di Kabupaten Buleleng memerlukan teknik untuk menggali informasi sehingga dapat mencerminkan keseluruhan potensi terutama potensi sumber daya pesisir. Bentuk wilayah yang sempit dan memanjang dari timur ke barat dengan 
karakteristik topografi pantai yang berbeda, maka diperlukan pembagian zone berdasarkan karakteristiknya tersebut. Pembagian tiga zone dan analisis masing-masing potensi sudah dapat menggambarkan potensi sumber daya pesisir di Kabupaten Buleleng sehingga dapat menyusun strategi pemberdayaan masyarakat wilayah pesisir. adapun potensi sumber daya pesisir di Kabupaten Buleleng yaitu sebagai berikut.

\section{Sumberdaya Hayati \\ 1) Sumberdaya Ikan}

Wilayah pesisir Kabupaten Buleleng memiliki potensi sumberdaya ikan yang melimpah. Ikan merupakan potensi sumberdaya pesisir utama bagi masyarakat pesisir. Kabupaten Buleleng yang sebagian wilayahnya merupakan wilayah pesisir, tidak menghapus tradisi masyarakatnya sebagai nelayan. Keadaan geografis yang berupa dataran rendah pinggir laut menyebabkan masyarakat di Kabupaten Buleleng berprofesi sebagai nelayan untuk memenuhi kebutuhan hidup sehari-hari. Menurut ketua kelompok nelayan Desa Pemaron (Ariasa), Kalibukbuk (Made Budiasa) dan Temukus (Ketut Sarka) pada sektor perikanan tangkap, Kabupaten Buleleng memiliki komoditi perikanan tangkap seperti ikan dan cumi-cumi. Jenis-jenis ikan yang biasa ditangkap oleh nelayan di Kabupaten Buleleng adalah ikan jenis kerapu, kakap dan tongkol, tuna karena jenis ikan tersebut banyak terdapat di perairan Bali Utara. Selain ikan, hasil tangkapan lainnya adalah cumi-cumi ukuran kecil. Hasil penelitian menunnjukkan Para nelayan biasa mengakap ikan selama 7-8 jam dalam sekali melaut dengan hasil tangkapan ikan sebanyak 50 hingga 90 kilogram. Armada penangkapan ikan yang digunakan nelayan di Kabupaten Buleleng digolongkan atas tiga jenis yaitu tanpa perahu, perahu tanpa motor dan perahu motor. Penangkapan ikan oleh nelayan dengan armada perahu tanpa motor maupun tanpa perahu dilakukan di perairan dangkal, sedangkan penangkapan ikan dengan armada perahu motor dilakukan di perairan yang lebih dalam sejauh 24 40 mil. Selain itu alat penangkapan ikan yang digunakan oleh nelayan di Kabupaten Buleleng masih tergolong tradisional atau sederhana yaitu pancing dan jaring.

\section{2) Potensi Terumbu Karang}

Terumbu karang merupakan salah satu kekayaan alam yang bernilai tinggi. Manfaat yang terkandung di dalam ekosistem terumbu karang sangat besar dan beragam, baik manfaat langsung maupun manfaat tidak langsung. Wilayah pesisir Kabupaten Buleleng memiliki sebaran terumbu karang yang cukup panjang.

Ekosistem terumbu karang di Kabupaten Buleleng berada kurang lebih 50 meter dari garis pantai, sepanjang pantai Desa Pemaron, Tukadmungga, Anturan, Kalibukbuk, Kaliasem dan Temukus. Terumbu karang yang terdapat di Kabupaten Buleleng memiliki luas penyebaran sebesar $1,5 \mathrm{~km}^{2}$ (Jurnal Sains dan Teknologi 2012). Terumbu karang di Kabupaten Buleleng secara umum dikategorikan sebagai terumbu karang tepi (fringing reefs) yang merupakan terumbu karang yang hidup disepanjang pantai, meskipun di beberapa titik pengamatan ditemukan tipe terumbu karang penghalang (barrier reef) yang berupa atol.

Terumbu karang mempunyai fungsi dan manfaat serta arti yang sangat penting bagi kehidupan masyarakat pesisir di Kabupaten Buleleng baik dari segi ekologi, ekonomi dan penunjang pariwisata. Secara ekologi terumbu karang memiliki manfaat yaitu (1) secara langsung terumbu karang menjadi penunjang kehidupan berbagai jenis makhluk hidup yang ada di sekitarnya sebagai tempat tinggal, mencari makan dan berkembang biak bagi biota laut, (2) terumbu karang mampu memperkecil 
energi ombak yang menuju ke daratan, sehingga mencegah terjadinya abrasi pantai. Terumbu karang secara langsung maupun tidak langsung menjadi sumber ekonomi bagi masyarakat. Keberadaan terumbu karang menunjang perekonomian masyarakat pesisir di Kabupaten Buleleng. Pengembangan terumbu karang menjadi objek wisata mampu menciptakan berbagai lapangan pekerjaan bagi masyarakat di Kabupaten Buleleng.

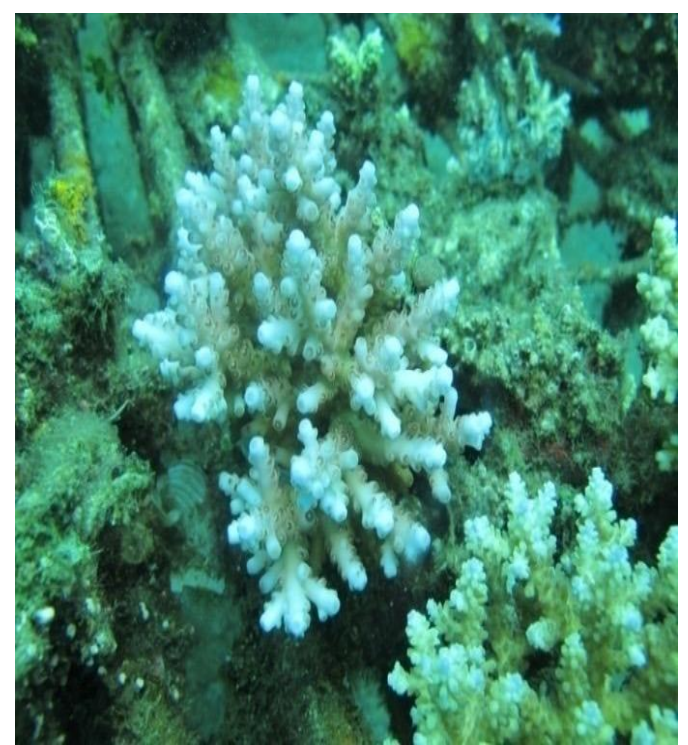

Gambar 1. Terumbu Karang (Sumber: Ananda, 2016)

\section{Jasa-Jasa Lingkungan}

Pariwisata alam merupakan sektor yang potensial untuk dikembangkan. Wisata Bahari adalah salah satu wisata andalan Kabupaten Buleleng dengan menyuguhkan pesona keindahan alam yang terletak diantara pegunungan dan laut. Kabupaten Buleleng menyediakan beranekaragam sumberdaya laut yang biasanya diasosiasikan dengan tiga "S" (sun, sea and sand).

Jenis layanan wisata bahari yang terdapat di Kabupaten Buleleng adalah mengamati atraksi lumba-lumba, memancing, diving, dan snorkeling. Lumba-lumba yang terdapat di Kabupaten Buleleng tepatnya di Lovina merupakan salah satu potensi yang memiliki daya tarik tersendiri bagi wisatawan domestik maupun mancanegara. Wisatawan yang ingin melihat atraksi lumba-lumba harus melakukan perjalan pagi-pagi karena lumba-lumba di kawasan ini hanya muncul antara pukul 6 hingga pukul 8 pagi. Pada jam tersebut, puluhan lumbalumba akan beratraksi secara alami menunjukkan kegiatan mereka, ada yang sekedar berenang di permukaan air dan ada juga yang melompat-lompat, dapat dilihat pada Gambar 2.

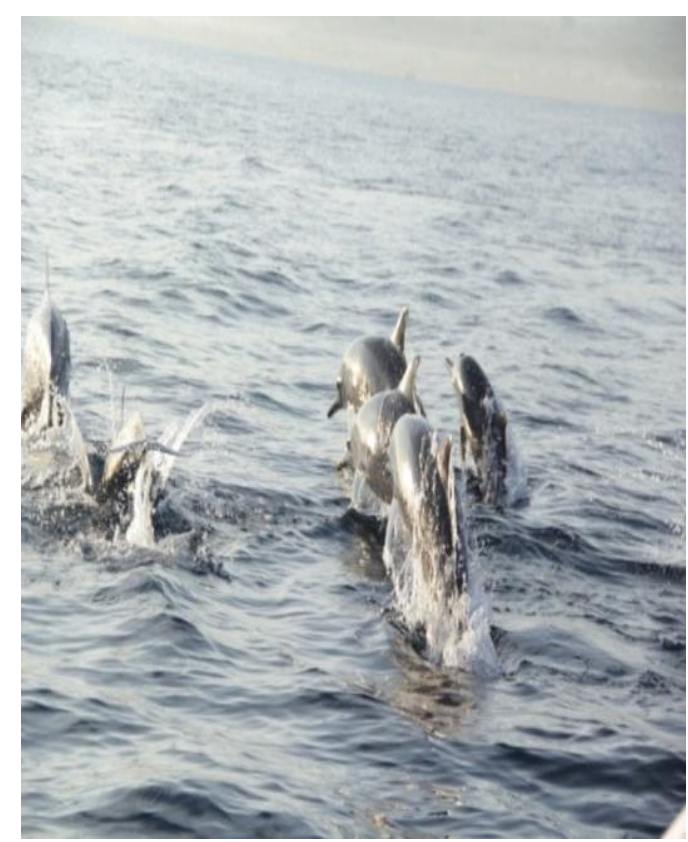

Gambar 2. Atraksi Lumba-Lumba

(Sumber: Ananda, 2016)

Keindahan alam yang terdapat di Kabupaten Buleleng tidak hanya di sekeliling pantainya saja tetapi juga yang berada di dalam air dengan cara melakukan diving ataupun snorkeling. Ada beranekaragan ikan hias dan terumbu karang yang dapat dilihat di dalam laut bila wisatawan diving di spot bagian taman lautnya.

Hal ini lebih banyak terdapat di Desa Pemuteran dengan budidaya terumbu karang yang dikenal dengan Biorock menjadi daya tarik wisata utama dapat dilihat pada Gambar 3. Selain dapat melihat pemandangan pantai dan lautan, wisatawan juga dapat melihat 
pemandangan gunung jika mengahadap kearah selatan.

Banyak kegiatan yang dapat dilakukan oleh para wisatawan saat berkunjung yaitu berjalan-jalan di sepanjang pesisir pantai sambil menikmati pemandangan alam yang indah dan dapat berfoto serta menikmati indahnya matahari terbenam (sunset), dapat dilihat pada Gambar 4.

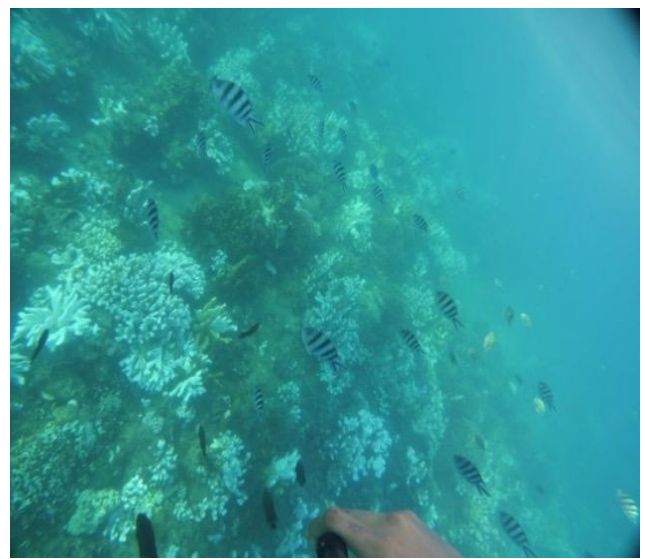

Gambar 3. Taman Laut

(Sumber: Ananda, 2016)

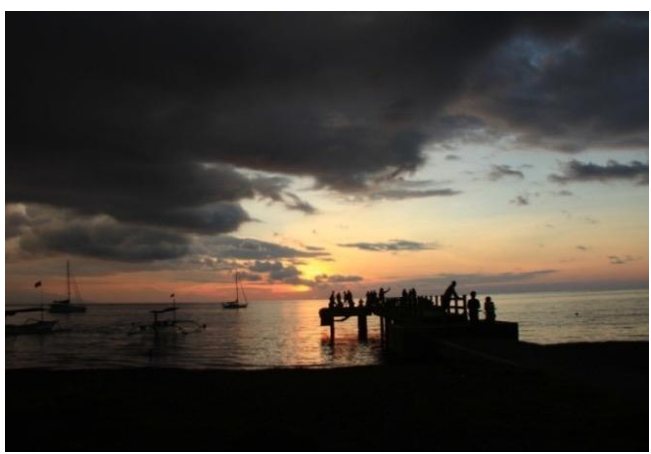

Gambar 4. Sunset di Pesisir Buleleng

(Sumber: Ananda, 2016)

Di Kawasan pesisir khususnya di Pantai Lovina juga berkembang fasilitasfasilitas penunjang pariwisata atau akomodasi selama kegiatan kepariwisataan berlangsung, seperti penginapan mulai dari homestay hingga hotel berbintang, rumah makan, dan bagi wisatawan yang ingin melakukan penyelaman atau ingin berkeliling menaiki perahu atau dalam bahasa lokal disebut jukung. Selain itu pengelola wisata pantai Lovina juga sudah menyediakan fasilitas-fasilitas lain seperti toko souvenir, pos keamanan, klinik kesehatan, pusat informasi, toilet umum dan tempat ibadah.

\section{Sumberdaya Buatan}

Sumberdaya buatan yaitu potensi yang dapat mendukung kegiatan di wilayah pesisir Buleleng yang dibuat oleh manuasia atau masyarakat sekitar. Adapun sumber daya buatan yag terdapat di wilayah pesisir yaitu dermaga Pantai Lovina merupakan aset Kementerian Pariwisata dan Ekonomi Kreatif Republik Indonesia dan satu dari sembilan jenis bangunan yang ada di wilayah objek wisata Lovina. Tujuan awal pembangunan Dermaga Pantai Lovina ini adalah untuk bersandarnya kapal Gross Tonage dan untuk bersandarnya perahu jukung nelayan wisata pengantar wisatawan menyaksikan lumba-lumba. Pemandian umum Air sanih di Desa Bukti yang dijadikan daya tarik pariwisata. Kabupaten Buleleng sudah dikenal di dunia Internasional, dermaga Pantai Lovina ini akan dikembangkan menjadi dermaga kapal pesiar sebagai tempat bersandarnya kapal pesiar dari berbagai negara. Pengembangan dermaga tersebut akan memberikan akses lebih kepada para wisatawan yang berkunjung ke Kawasan Pantai Lovina. Pembangunan Dermaga Pantai Lovina bertaraf Internasional akan mempengaruhi peningkatan kunjungan wisatawan ke wilayah Bali Utara. Sehingga akan meningkatkan pembangunan daerah di bidang pariwisata.

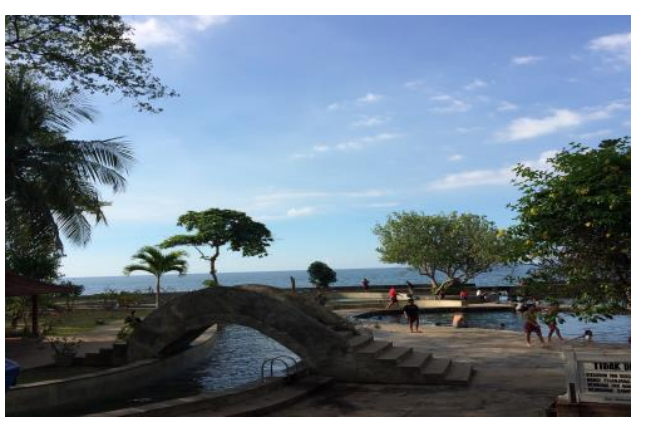

Gambar 5. Pemandian air sanih (Sumber: Ananda, 2016)

Jurnal IImu Sosial dan Humaniora | 36 


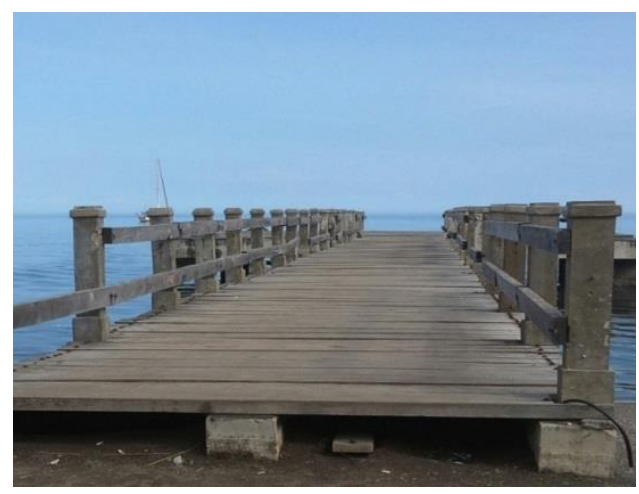

Gambar 6. Dermaga Pantai Lovina Sumber: (Ananda, 2016)

\section{Strategi Pengelolaan Sumber daya Pesisir untuk Pemberdayaan Masyarakat Wilayah Pesisir Kabupaten Buleleng}

Dalam pemanfaatan sumberdaya pesisir tentunya tidak terlepas dari berbagai kendala, untuk meminimalisir kendala tersebut perlu adanya strategi dalam pengelolaan potensi sumberdaya pesisir. Potensi sumberdaya pesisir oleh masyarakat di Kabupaten Buleleng telah lama diketahui dan juga disadari bahwa potensi sumberdaya pesisir yang ada memiliki berbagai macam manfaat baik langsung maupun tidak langsung bagi kehidupan masyarakat setempat. Pengelolaan sumberdaya pesisir di Kabupaten Buleleng, secara umum akan dipengaruhi oleh lingkungan strategis wilayahnya, baik lingkungan internal maupun eksternal, yang dapat menentukan tingkat keberhasilan pemanfaatan dan pengambangannya. Untuk lingkungan internal secara sinergis akan menentukan kekuatan (strengths) dan kelemahan (weaknesses) masyarakat, pengelola wisata dan pemerintah dalam menyikapi permasalahan yang ada maupun yang akan datang dalam pengelolaan sumberdaya pesisir. Lingkungan eksternal akan menentukan peluang (opportunities) dan ancaman (threatst) yang akan dihadapi oleh pemerintah, masyarakat, dan pengelola wisata dalam mengelola sumberdaya pesisir. Rencana strategis dalam pengelolaan sumberdaya pesisir dirangkum dalam matrik SWOT. Hasil strategi alternatif untuk pengelolaan sumberdaya pesisir dapat dilihat pada Tabel 1.

Tabel 1. Strategi Alternatif Kombinasi SO, WO, ST, dan WT

\begin{tabular}{|c|c|c|}
\hline Eksternal & $\begin{array}{l}\quad \text { Opportunities (0) } \\
\text { 1. Permintaan ikan tinggi } \\
\text { 2. Populasi ikan karang } \\
\text { 3. Jumlah wisatawan } \\
\text { meningkat }\end{array}$ & $\begin{array}{l}\text { Threats }(\mathbf{T}) \\
\text { 1. Masuknya produk } \\
\text { perikanan dari luar } \\
\text { daerah } \\
\text { 2. Eksploitasi terumbu } \\
\text { karang } \\
\text { 3. Persaingan pariwisata } \\
\text { cukup tinggi }\end{array}$ \\
\hline Strengths (S) & Strategi S-O & Strategi S-T \\
\hline $\begin{array}{l}\text { 1. Potensi ikan } \\
\text { 2. Potensi } \\
\text { terumbu karang } \\
\text { 3. Memiliki daya } \\
\text { tarik wisata } \\
\text { 4. Lingkungan } \\
\text { sekitar pantai } \\
\text { asri dan }\end{array}$ & $\begin{array}{l}\text { 1. Pembudidayaan ikan } \\
\text { 2. Pelestarian terumbu } \\
\text { karang } \\
\text { 3. Pelatihan peningkatan } \\
\text { pelayanan wisata } \\
\text { 4. Pemeliharaan } \\
\text { lingkungan sekitar } \\
\text { pantai agar tetap asri }\end{array}$ & $\begin{array}{l}\text { 1. Menambah produk } \\
\text { perikanan dalam } \\
\text { daerah } \\
\text { 2. Penegakan hukum } \\
\text { atau awig-awig } \\
\text { beserta sanski } \\
\text { 3. Menjaga potensi } \\
\text { wisata dengan baik }\end{array}$ \\
\hline
\end{tabular}




\begin{tabular}{|c|c|c|}
\hline nyaman & dan nyaman & $\begin{array}{l}\text { 4. Meningkatkan } \\
\text { kesadaran } \\
\text { masyarakat untuk } \\
\text { menjaga lingkungan } \\
\text { sekitar pantai }\end{array}$ \\
\hline $\begin{array}{l}\text { Weaknesses (W) } \\
\text { 1. Belum adanya } \\
\text { pasar khusus } \\
\text { untuk menjual } \\
\text { ikan } \\
\text { 2. Rendahnya } \\
\text { kualitas SDM } \\
\text { masyarakat } \\
\text { lokal dalam } \\
\text { pengelolaan } \\
\text { terumbu karang } \\
\text { 3. Usaha produk } \\
\text { kerajinan } \\
\text { tangan masih } \\
\text { rendah }\end{array}$ & $\begin{array}{l}\text { Strategi W-O } \\
\text { 1. Penyediaan tempat } \\
\text { pelelangan ikan } \\
\text { 2. Memberikan pelatihan } \\
\text { kepada masyarakat } \\
\text { tentang pelestarian } \\
\text { terumbu karang } \\
\text { 3. Pengadaan modal bagi } \\
\text { usaha-usaha } \\
\text { masyarakat dalam } \\
\text { membuat kerajinan } \\
\text { tangan }\end{array}$ & \begin{tabular}{l}
\multicolumn{1}{c}{ Strategi W-T } \\
1. Memberikan batasan \\
masuknya produk \\
perikanan dari luar \\
daerah. \\
2. Meningkatkan \\
kesadaran \\
masyarakat tentang \\
pentingnya menjaga \\
sumberdaya terumbu \\
karang \\
3. Menjalin kerja sama \\
dengan kalangan \\
swasta dan \\
pemerintah dalam \\
meningkatkan produk \\
kerajinan tangan
\end{tabular} \\
\hline
\end{tabular}

Dalam pengelolaan sumberdaya pesisir di Kabupaten Buleleng perlu adanya strategi. Perumusan rencana strategi pengelolaan sumberdaya pesisir di Kabupaten Buleleng dilakukan dengan menggunakan analisis SWOT dengan menganalisis faktor-faktor internal dan eksternal yang terdapat di Kabupaten Buleleng.

Strategi pengelolaan potensi sumberdaya pesisir di Kabupaten Buleleng berdasarkan tabel 1 dengan analisis SWOT, baik internal maupun eksternal dijelaskan adalah sebagai berikut.

\section{1) Strategi Kekuatan-Kesempatan (S dan O)}

(1) Pembudidaayan ikan.

Pembudidayaan ikan akan memberikan nilai tambah yang besar terhadap pendapatan masyarakat lokal setempat yang bekerja terkait dengan sumberdaya pesisir yang terdapat di Kabupaten Buleleng.
(2) Pelestarian terumbu karang.

Pelestarian terumbu karang dilakukan dengan tujuan untuk menjaga ekosistem terumbu karang dari kerusakan akibat faktor alam maupaun manusia.

(3) Pelatihan peningkatan pelayanan wisata.

Tujuan pelatihan peningkatan pelayanan wisata adalah untuk meningkatkan kemampuan dan keterampilan masyarakat Kabupaten Buleleng yang bekerja di sektor pariwisata.

(4) Pemeliharaan lingkungan pantai agar tetap asri dan nyaman.

Pemeliharan lingkungan pantai di Kabupaten Buleleng merupakan salah satu upaya untuk memberikan kenyamanan bagi setiap pengunjung yang datang ke pantai. Sehingga dengan kondisi lingkungan yang asri dan nyaman akan dapat meningkatkan jumlah kunjungan wisatawan. 


\section{2) Strategi Kesempatan (W dan O)}

(1) Penyediaan tempat pelelangan ikan.

Dengan tersedianya tempat pelelangan ikan akan memudahkan para nelayan memasarkan hasil tangkapannya.

(2) Memberikan pelatihan kepada masyarakat tentang pelestarian terumbu karang.

Tujuan pemberian pelatihan ini guna meningkatkan pengetahuan dan keterampilan masyarakat untuk melestarikan terumbu karang yang ramah.

(3) Pengadaan modal bagi usahausaha masyarakat dalam membuat kerajinan tangan.

Tujuan dari adanya pengadaan modal tersebut adalah untuk meningkatkan kualitas kerajinan tangan yang dibuat oleh masyarakat lokal setempat.

\section{3) Strategi Kekuatan-Ancaman (S dan T)}

(1) Menambah produk perikanan dalam daerah tujuannya adalah untuk dapat memenuhi permintaan ikan yang tinggi.

(2) Penegakan hukum atau awigawig beserta sanksi adalah untuk memberikan sanksi terhadap oknum yang melakukan ekspoitasi terumbu karang.

(3) Menjaga potensi wisata bertujuan untuk mempertahankan kekhasan wisata yang dimiliki.

(4) Meningkatkan kesadaran masyarakat untuk menjaga lingkungan sekitar pantai. Kesadaran masyarakat terhadap lingkungan ini bertujuan agar lingkungan sekiar pantai tetap bersih sehingga dapat memberikan kenyamanan bagi setiap pengunjung yang datang.
4) Strategi Kelemahan-Ancaman (W dan $T$ )

(1) Memberikan batasan masuknya produk perikanan dari luar daerah. Pembatasan ini bertujuan untuk lebih mengutamakan produk perikanan dalam daerah.

(2) Meningkatkan kesadaran masyarakat tentang pentingnya menjaga sumberdaya terumbu. Kesadaran masyarakat terhadap ekosistem terumbu karang sangat penting karena terumbu karang akan memberikan berbagai manfaat yang besar untuk biota laut dan masyarakat itu sendiri.

(3) Menjalin kerja sama dengan kalangan swasta dan pemerintah dalam meningkatkan produk kerajinan tangan. adanya kerjasama dengan pihak swasta dan pemerintah dapat meningkatkan produk kerajianan tangan dalam skala besar Startegi pengelolaan sumberdaya pesisir Kabupaten Buleleng antaranya pembudidayaan ikan, pelestarian terumbu karang, pelatihan peningkatan pelayanan wisata, pemeliharaan lingkungan pantai agar tetap asri dan nyaman, penyediaan fasilitas tempat pelelangan ikan, memberikan pelatihan kepada masyarakat tentang pelestarian terumbu karang, pengadaan modal bagi usaha-usaha masyarakat dalam membuat kerajinan tangan, menambah produk perikanan dalam daerah, penegakan hukum atau awig-awig beserta sanski, menjaga potensi wisata dengan baik, meningkatkan kesadaran masyarakat untuk menjaga lingkungan sekitar pantai, memberikan batasan masuknya produk perikanan dari luar daerah, meningkatkan kesadaran masyarakat tentang pentingnya menjaga sumberdaya terumbu, menjalin kerja sama dengan kalangan swasta dan pemerintah 
dalam meningkatkan produk kerajinan tangan.

\section{SIMPULAN DAN REKOMENDASI}

\section{Simpulan}

Berdasarkan hasil dan pembahasan dari tujuan penelitian, maka dapat ditarik 2 kesimpulan sebagai berikut.

1) Potensi sumber daya pesisir yang berada di wilayah pesisir Kabupaten Buleleng secara umum beraneka ragam. Seperti perikanan, budidaya terumbu karang, dan pemanfaatan di bidang pariwisata. Adapun potensi yang belum di lakukan adalah budidaya ikan.

2) Strategi pemberdayaan masyarakat pesisir sangat penting untuk dibuat dan dilakasanakan. Nelayan hanya baru sebatas menangkap saja. Perlunya pemberdayaan masyarakat dalam pembudidayaan perikanan. Di bidang pariwisata strategi yang bisa dikembangkan yaitu di pada kerajinan cendera mata karena barang-barang souvenir didatangkan dari luar desa bahkan dari luar kabupaten.

2. Rekomendasi

Adapun rekomendasi yang dapat diberikan adalah sebagai berikut.

1) Bagi Pemerintah Kabupaten Buleleng dalam rangka pembangunan wilayah khususnya wilayah pesisir dalam bidang pariwisata agar mulai untuk berorietasi pada pengembangan ekowisata utamanya pemberdayaan masyarakat sumber daya pesisir di Kabupaten Buleleng dari hasil penelitian ini memiliki potensi memenuhi persyaratan pengembangan ekowisata.

2) Bagi Desa Adat agar menjadikan awig-awig desa sebagai bingkai kegiatan pariwisata. DTW yang ada di bagian wewidangan (areal desa) wajib mentaati kearifan lokal yang dimiliki desa adat, sehingga kelestarian alam dan budaya yang dimiliki tidak pudar.

3) Bagi masyarakat pesisir agar lebih memanfaatkan peluang usaha berdasarkan potensi sumberdaya pesisir yang dimiliki.

\section{UCAPAN TERIMAKASIH}

Terimakasih pada Universitas Pendidikan Ganesha dan Lembaga Penelitian Undiksha khususnya dalam memberikan kesempatan, izin dan kontribusi berupa dana penelitian dengan nomor surat kontrak penelitian: $\quad$ 59/UN48.15/LT/2016 sehingga penelitian dapat berjalan dan selesai tepat waktu.

\section{DAFTAR PUSTAKA}

Baiquni, M. 2010. Pariwisata Berkelanjutan dalam Pusaran Krisis Global. Denpasar: Udayana University Press.

Efendi, Sofian dan Singarimbun, Masri. 1987. Metode Penelitian Survai. Yogyakarta: LP3ES

Pigawati, Bitta. 2005. Identifikasi Potensi dan Pemetaan Sumberdaya Pesisir Pulau Pulau Kecil dan Laut Kabupaten Natuna - Provinsi Kepulauan Riau. Jurnal IImu Kelutan Vol. 10 No. 4, 229-236 Desember 2005.

Pendit. 2002. Ilmu Pariwisata Sebuah Pengantar Perdana. Jakarta : Pradnya Paramitha.

Western, David. 1995. Ekoturisme: Petunjuk Untuk Perencanaan \& Pengelolaan. Jakarta: The Ecotourism Society North Benington, Vermont.

Yunus, Hadi Sabari. 2010. Metode Penelitian Wilayah Kontemporer. Yogyakarta: Pustaka Pelajar 
http://www.bulelengkab.go.id/index.ph

$\mathrm{p} /$ pariwisata/19/Wisata-Alam

Diakses tanggal 15 April 2015 